\title{
Karakterisasi Sampah di Lingkungan Universitas Lampung
}

\author{
Pramita Sari Anungputria ${ }^{a}$ Puspita Yuliandari ${ }^{b}$, Erdi Suroso $^{c}$
}

Program Studi Teknologi Industri Pertanian, Jurusan Teknologi Hasil Pertanian Fakultas Pertanian Universitas Lampung, Bandar Lampung, 35141

email korespondensi: a pramita.sari@fp.unila.ac.id, ${ }^{b}$ puspita.yuliandari@fp.unila.ac.id,

cerdi.suroso@fp.unila.ac.id,

\begin{abstract}
The issue of waste is one of the important problems that arise in the University of Lampung region along with the increasing number of campus residents. Waste characterization is very important to know the right treatment for waste management. This study aims to examine the characteristics of waste at the University of Lampung. Waste in the University of Lampung is classified into 4 types, namely dry waste, wet waste, ash waste and street waste with 3 test parameters, namely testing of moisture content, density and calorie value. The results showed that dry waste had water content, density and calorie value of $4,68 \% ; 55,81 \mathrm{~kg} / \mathrm{m}^{3}$ and $17,6 \mathrm{MJ} / \mathrm{kg}$, wet waste has water content, density and calorie value of $87,37 \% ; 902,80 \mathrm{~kg} / \mathrm{m}^{3}$ and $15,90 \mathrm{MJ} / \mathrm{kg}$, ash waste has water content, density and calorie value of $4,71 \% ; 81,20 \mathrm{~kg} / \mathrm{m}^{3}$ and $2.89 \mathrm{MJ} / \mathrm{kg}$ as well as the last sample, namely road waste has water content, density and calorie value of $11.11 \% ; 352,25$ $\mathrm{kg} / \mathrm{m}^{3}$ and $12,81 \mathrm{MJ} / \mathrm{kg}$.
\end{abstract}

Keyword: waste management, waste characterization, lampung university

Abstrak. Persoalan sampah merupakan salah satu masalah penting yang timbul di kawasan Universitas Lampung seiring dengan meningkatnya jumlah civitas akademika di lingkungan kampus. Karakterisasi sampah sangat penting untuk dilakukan untuk mengetahui proses pengelolaan sampah yang tepat guna. Penelitian ini bertujuan untuk mengkaji karakteristik sampah di lingkungan Universitas Lampung. Sampah di lingkungan Universitas Lampung diklasifikasikan menjadi 4 kategori yaitu sampah kering, sampah basah, sampah abu dan sampah jalanan dengan parameter pengujian yaitu pengujian kadar air, densitas dan nilai kalori. Hasil penelitian menunjukkan bahwa sampah kering memiliki kadar air, densitas dan nilai kalori sebesar 4,68\%; 55,81 kg/m³ dan 17,6 $\mathrm{MJ} / \mathrm{kg}$, sampah basah memiliki kadar air, densitas dan nilai kalori sebesar $87,37 \% ; 902,80 \mathrm{~kg} / \mathrm{m}^{3}$ dan $15,90 \mathrm{MJ} / \mathrm{kg}$, sampah abu memiliki kadar air, densitas dan nilai kalori sebesar 4,71\%; $81,20 \mathrm{~kg} / \mathrm{m}^{3}$ dan $2,89 \mathrm{MJ} / \mathrm{kg}$ serta sampel yang terakhir yaitu sampah jalanan memiliki kadar air, densitas dan nilai kalori sebesar $11,11 \% ; 352,25 \mathrm{~kg} / \mathrm{m}^{3}$ dan $12,81 \mathrm{MJ} / \mathrm{kg}$.

Keyword: pengelolaan sampah, karakterisasi sampah, universitas lampung

\section{Pendahuluan}

Pencemaran

lingkungan merupakan permasalahan global yang sampai saat ini masih dicarikan solusi terbaiknya. Salah satu penyebab dari pencemaran lingkungan yang sangat dekat dengan kehidupan sehari-hari dan kurang menjadi perhatian dari masyarakat adalah sampah. Sampah merupakan barang yang dianggap sudah tidak terpakai dan dibuang oleh pemilik/pemakai sebelumnya, tetapi bagi sebagian orang masih bisa dipakai jika dikelola dengan prosedur yang benar. Produksi wadah makanan, alat elektronik, alat kosmetik, hingga pakaian yang kita kenakan akan menjadi sampah saat kita sudah tidak memakainya lagi. Penyianyiaan terhadap makanan pun masih tinggi yang membuat banyak makanan atau minuman yang di buang. Peningkatan produksi sampah pun menjadi permasalah global karena beberapa 
jenis sampah sulit untuk diurai terutama sampah plastik dan sampah elektronik.

Timbulan sampah pada lingkungan universitas umumnya berasal dari aktivitas belajar mengajar, konsumsi makanan, pembangunan gedung serta pepohonan hijau. $\mathrm{Di}$ lingkungan Universitas Lampung setiap harinya menghasilkan sampah $\pm 770 \mathrm{~kg}$ yang sebagian besar didominasi oleh sampah organik seperti kertas bekas, sisa makanan, dan sampah pepohonan, serta sampah anorganik seperti kemasan plastik. Sampah yang dihasilkanden sebagian besar (95\%) ditimbun dan dibakar di suatu lahan Tempat Pembuangan Sementara sebelum dibawa ke Tempat Pembuangan Akhir.

Adanya peningkatan jumlah mahasiswa dan civitas akademika kampus mengakibatkan tuntutan dalam pemenuhan pengelolaan sampah kampus yang baik dan tepat. Pengelolaan sampah dapat dilakukan melaui pengurangan dan penanganan sampah. Agar masalah persampahan dapat teratasi secara tepat guna terlebih dahulu perlu diketahui mengenai komposisi, dan karakteristik sampah yang dihasilkan. Data tentang komposisi sampah kota sangat penting untuk pemilihan alternatif manajemen sampah seperti daur ulang [1]. Dalam rangka menyelenggarakan pengelolaan sampah kampus Universitas Lampung secara terpadu, komprehensif, dan sesuai dengan hak dan kewajiban civitas akademika serta tugas dan wewenang kelembagaan, maka dibutuhkan arahan dan solusi dalam pengelolaan sampah di Universitas Lampung sebagai usaha untuk mengatasi permasalahan persampahan yang ada.

\section{Metode Penelitian}

Penelitian ini dilakukan dengan melakukan sampling sampah organik yang berada pada Tempat Pembuangan Sementara Universitas Lampung (TPS Unila). Sampah organik yang diambil yaitu sampah dengan kategori sampah kering, sampah basah, sampah jalanan, dan sampah abu. Pengujian karakteristik sampah dilakukan terhadap kadar air sampah, kadar abu, densitas, dan nilai kalori sampah

\section{Kadar Air}

Metode pengukuran kadar air sampah yang dilakukan pada penelitian ini adalah metode pengukuran berat basah [2]. Metode pengukuran berat basah menyatakan kandungan air sampah sebagai persentase berat basah material. Dalam bentuk persamaan, kandungan air berat basah dinyatakan sebagai berikut:

$$
M(\%)=\frac{w-d}{w} \times 100 \%
$$

Keterangan : $\mathrm{M}=$ kandungan air (\%); $\mathrm{W}$ = berat sampel awal (gram); $d=$ berat sampel setelah pemanasan (gram).

\section{Densitas}

Volume sampah diperoleh dari hasil pengukuran terhadap volume sampah pada pertambahan volume sampah yang dimasukkan dalam gelas ukur berisi $50 \mathrm{~mL}$ air. Berat sampah diperoleh dari hasil pengukuran terhadap pertambahan berat sampah yang dimasukkan dalam gelas ukur berisi 50 $\mathrm{mL}$ air. Melalui data tersebut, selanjutnya dapat dihitung densitas sampah menggunakan Persamaan 2 [3]. 


$$
\operatorname{Densitas} \operatorname{Sampah}\left(\mathrm{kg} / \mathrm{m}^{3}\right)=\frac{\operatorname{Berat} \operatorname{Sampah}(\mathrm{kg})}{\operatorname{Volume} \operatorname{Sampah}\left(\mathrm{m}^{3}\right)}
$$

\section{Nilai Kalori}

Pengukuran Kalori atau Gross Energy dilakukan dengan menggunakan sampel yang sudah dikeringkan dengan oven lalu diukur kadar kalorinya dengan menggunakan Bomb Calorimeter CAL2K.

\section{Hasil Dan Pembahasan}

Pengelolaan sampah adalah kegiatan yang sistematis, menyeluruh, dan berkesinambungan yang meliputi pengurangan dan penanganan sampah. Kegiatan penanganan meliputi pemilahan, pemanfaatan kembali (reuse) dan daur ulang (recycle) yang bertujuan untuk mereduksi besarnya timbulan sampah (reduce) [4]. UU Nomor 18 Tahun 2008 pasal 4 menyebutkan bahwa pengelolaan sampah bertujuan untuk meningkatkan kesehatan masyarakat dan kualitas lingkungan serta menjadikan sampah sebagai sumber daya. Pengelolaan sampah harus dilaksanakan secara tepat guna sesuai dengan karakteristik sampah yang dihasilkan.

Pemilahan sampah menjadi sampah organik dan anorganik merupakn langkah awal yang dapat dilakukan untuk dapat mengolah sampah secara tepat guna. Karakterisasi sampah perlu dilakukan utuk mempermudah proses pengolahan sampah. Karakterisasi sampah dilakukan terhadap empat kategori sampah yang terdapat pada Tempat Pembuangan Sementara Universitas Lampung, yaitu sampah kering, sampah abu, sampah basah, dan sampah jalanan. Komposisi sampah yang berada di lingkungan Universitas Lampung terdiri atas $30 \%$ sampah kering, $15 \%$ sampah basah, 15\% sampah abu dan $40 \%$ sampah jalanan.

Sampah basah (garbage) merupakan jenis sampah yang terdiri dari sisa sisa potongan hewan atau sayur-sayuran hasil dari pengolahan, pembuatan dan penyediaan makanan yang sebagian besar terdiri dari zat-zat yang mudah menbusuk. Sampah kering (rubbish) adalah sampah yang dapat terbakar dan tidak dapat terbakar yang berasal dari rumah-rumah, pusat-pusat perdangangan, kantor-kantor. Abu (Ashes) adalah sampah yang berasal dari sisa pembakaran dari zat yang mudah terbakar seperti rumah, kantor maupun dipabrik-pabrik industri. Sampah jalanan (street sweping) adalah sampah yang berasal dari pembersihan jalan dan trotoar baik dengan tenaga manusia maupun dengan tenaga mesin yang terdiri dari kertas kertas, dedaun daunan dan lain lain [5]. Hasil pengujian terhadap sampah disajikan pada Tabel 1.

Tabel 1. Hasil Pengujian Sampah

\begin{tabular}{llll}
\hline $\begin{array}{l}\text { Kategori } \\
\text { Sampah }\end{array}$ & Kadar Air & Densitas & $\begin{array}{l}\text { Nilai } \\
\text { Kalori }\end{array}$ \\
\hline Sampah & $4,68 \%$ & 55,81 & 17,6 \\
Kering & & $\mathrm{kg} / \mathrm{m}^{3}$ & $\mathrm{MJ} / \mathrm{kg}$ \\
Sampah & $4,71 \%$ & 81,20 & 2,89 \\
Abu & & $\mathrm{kg} / \mathrm{m}^{3}$ & $\mathrm{MJ} / \mathrm{kg}$ \\
Sampah & $87,37 \%$ & 902,80 & 15,90 \\
Basah & & $\mathrm{kg} / \mathrm{m}^{3}$ & $\mathrm{MJ} / \mathrm{kg}$ \\
Sampah & \multirow{2}{*}{$11,11 \%$} & 352,25 & 12,81 \\
Jalanan & & $\mathrm{kg} / \mathrm{m}^{3}$ & $\mathrm{MJ} / \mathrm{kg}$ \\
\hline
\end{tabular}

Kadar air yang terdapat pada empat kategori sampah tersebut sangat beragam. Kadar air tertinggi terdapat pada sampah basah yaitu $87,37 \%$. Tingginya kadar air pada sampah basah ini disebabkan karena sumber sampah tersebut berasal dari sisa-sisa makanan yang terbuang atau tidak habis yang masih memiliki kadar air yang tinggi. Kadar air yang tinggi pada sampah dapat mempengaruhi proses pengelolaan sampah berikutnya, 
dimana terdapat beberapa proses pengolahan yang mensyaratkan kadar air rendah sehingga diperlukan proses penghilangan kadar air terlebih dahulu [6].

Pada sampah jalanan mengandug kadar air sebesar $11,11 \%$. Sampah jalanan ini sebagian besar berasal dari dedaunan yang jatuh ddi pinggir jalan. Sumber sampah jalanan lainnya yang ditemukan berupa sisa kemasan makanan yang dibuang di pinggir jalan. Pada sampah kering dan sampah abu memiliki kadar air yang sangat minimum yaitu sebesar $4,68 \%$ dan $4,71 \%$. Hal ini disebabkan karena sumber sampah tersebut merupakan bahan yang kering serta sampah lain yang sudah dibakar sehingga menjadi abu. Pembakaran sampah menjadi abu dapat mengurangi volume timbunan nanum dapat menjadi permasalahan lain yaitu pencemaran udara sebagai efek dari pembakaran tersebut.

Densitas berperan penting dalam proses pengelolaan sampah, terutama dalam memperkirakan total massa dan total volume sampah yang harus ditangani [7]. Densitas sampah dinyatakan sebagai berat sampah per satuan volume $(\mathrm{kg} / \mathrm{m} 3)$. Densitas sampah yang besar terdapat pada sampah basah sebesar 902,80 kg.m3, sedangkan densitas sampah yang paling kecil terdapat pada sampah kering yaitu sebesar 55, $81 \%$ dan densitas yang palig besar dimiliki oleh sampah basah. Dengan data densitas tersebut dapat diketahui bahwa sampah basah akan memiliki volume yang relative lebih kecil dibandingkan dengan sampah kering pada berat yang sama. Hal tersebut juga menunjukan akan terbentuknya timbunan yang cukup banyak dan luas pada sampah dengan densitas yang lebih kecil.

Pengujian sampah terhadap kandungan kalorinya menunjukan bahwa sampah kering memiliki nilai kalori yang paling besar yaitu 17,6 $\mathrm{MJ} / \mathrm{kg}$, yang kemudian diikuti oleh nilai kalori dari sampah basah sebesar 15,90 $\mathrm{MJ} / \mathrm{kg}$, dan sampah jalanan sebesar $12,81 \mathrm{MJ} / \mathrm{kg}$. Nilai kalori pada sampah abu sangat kecil yaitu 2,89 MJ/kg yang disebabkan karena sampah tersebut telah mengalami proses pembakaran terlebih dahulu sehingga mengurang nilai kalori yang dikandungnya. Dengan adanya kandungan kalori yang terdapat dalam sampah serta volume timbunan sampah yang dihasilkan per hari cukup tinggi memungkinkan adanya peluang untuk pemanfaatan sampah sebagai sumber energi baru.

\section{Kesimpulan}

Permasalahan sampah merupakan isu global yang perlu penanganan tepat guna. Pengelolaan sampah harus sesuai dengan karakteristik sampah yang ada di lingkungan kampus Universitas Lampung. Komposisi sampah yang berada di lingkungan Universitas Lampung terdiri atas 30\% sampah kering, 15\% sampah basah, $15 \%$ sampah abu dan $40 \%$ sampah jalanan. Pengujian karakteristik sampah berdasarkan kategori sampah kering, sampah abu, sampah basah, dan sampah jalanan memberikan hasil bahwa sampah kering memiliki kadar air dan densitas yang paling rendah, serta memiliki nilai kalori yang paling tinggi.

\section{Daftar Pustaka}

[1] E. S. Sanneh, A. H. Hu, Y. M. Chang, and E. Sanyang, Introduction of a recycling system for sustainable municipal solid waste management : a case study on the greater Banjul area of the Gambia. Gambia: Environment, Development, and Sustainability, 
2011.

[2] G. Yogaswara, "Karakterisasi dan Analisis Potensi Kompos Sampah Padat Pasar Tradisional di Pasar Bogor," Institut Pertanian Bogor, 2013.

[3] H. Ratya and W. Herumurti, "Timbulan Dan Komposisi Sampah Rumah Tangga Di Kecamatan Rungkut Surabaya," J. Tek. ITS, vol. 6, no. 2, pp. C451-C453, 2017.

[4] I. P. Amurwaraharja, "Analisis Teknologi Pengolahan Sampah dengan Proses Hirarki Analitik dan Metoda Valuasi Kontingensi,"
Institut Pertanian Bogor, 2003.

[5] E. Damanhuri and Padmi, Diktat Kuliah Pengelolaan Sampah. Bandung: ITB, 2004.

[6] R. N. Yusfi and T. P. Damanhuri, "Studi Karakteristik dan Potensi Daur Ulang Sampah di Bantaran Sungai Cikapundung," J. Tek. Lingkung., vol. 18, no. 2, pp. 155166, 2012.

[7] P. Puspitasari, "Kajian Potensi Daur Ulang Sampah Anorganik Skala TPS dan TPA (Studi Kasus: Kota Bandung)," Institut Teknologi Bandung, 2008. 
Pramita Sari Anungputri dkk. : Karakterisasi Sampah di Lingkungan Universitas Lampung 